\title{
Dialogue
}

Robert (Bob) C Kiste: Mentor and Friend of the Pacific BRIJ V LAL

The Contemporary Pacific, Volume 3I, Number 2, 477-494

(C) 2019 by University of Hawai'i Press 


\section{Robert (Bob) C Kiste: Mentor and Friend \\ of the Pacific}

Brij V Lal

$\mathrm{T}_{\mathrm{h}}$

his article is drawn from the introduction to a previously published volume, Pacific Places, Pacific Histories: Essays in Honor of Robert C. Kiste (Lal 2004), which honors Bob Kiste and celebrates the contribution he made to the promotion of Pacific Islands studies in the latter half of the twentieth century.

By the time Bob retired from the University of Hawai'i-Mānoa (UHM) in July 2002, after serving as director of the Center for Pacific Islands Studies for twenty-four years, his reputation as the world's premier encourager and publisher of the best scholarly research on the Pacific Islands was secure. Colleagues, collaborators, research students, staff, friends, and admirers all benefited from Bob's support, generosity, and vision for Pacific Islands research. Bob was a remarkable person who embarked on a remarkable personal and professional journey, resulting in a fundamental, enduring contribution to Pacific Islands studies unlikely to be repeated anytime soon.

Like many others, Bob found his place in the Pacific Islands through chance-or fate, if you will. His was an improbable journey. Improbable, yes, but not exceptional, for while the roots and routes vary, with different points of departure and different personal and professional destinations, most of us have also come from just or nearly as improbable backgrounds. In Bob's unplanned and unpredictable journey, we can all recognize markers of our own special moments, coded allusion to our own various dispersals, sounds of our own footsteps. Like him, many of us are pioneers in our own way: the first in our families to graduate from college, enjoy secure academic careers, make enduring cross-cultural friendships, travel to distant and sometimes previously unheard of places, or simply do something outside the realm of family tradition. We are all full of "firsts"

The Contemporary Pacific, Volume 3I, Number 2, 478-494

(C) 2019 by University of Hawai' $i$ Press

478 
of one sort or another. Like many of us, Bob was a man of many places whose ideas and imagination of those places changed over time. Change, in fact, was a constant in Bob's life.

When I first proposed the idea of a book of essays to Bob sometime in the late 1990s-which appeared as Pacific Places, Pacific Histories in 2004- he was genuinely taken by surprise. He was flattered at the thought but felt he did not deserve the honor. He was that kind of person: product of an earlier generation, slightly reticent, emotionally uncomfortable in the public limelight, not one to bask in the glory of his achievements, always distributing credit around. When I persisted, he agreed to let me proceed but on the firm understanding that, while he would cooperate, he would prefer not to know what the book was about or who might be asked to contribute to it. I respected his request, eventually compiling a list of the "usual suspects" with the assistance of some of Bob's close friends and colleagues, all of whom agreed to abide by my request to keep the project secret from him.

When contributions began arriving on my desk, I needed to talk to Bob about his life. He agreed, though still with no firm idea of the theme of the proposed book nor of the contributors. We met in his office in UHM's Moore Hall in late January 2002, and over a weekend of sustained conversation, several hours long (all on tape), I obtained details of Bob's journey. He was completely candid about people and places he had encountered, about his own disadvantaged family life in the American Midwest, his professional work and its satisfactions and disappointments, and his reflections on the Island world he had come to call home. What follows is based largely on our conversation-but not all of it is, I should hasten to add, because some things in the privacy of a confidential conversation must perforce remain private.

Bob Kiste was born on 26 August 1936, into a poor family in remote, rural Spencer, Indiana, population two thousand. His father, Edgar, and his mother, Hazel, were typical Midwesterners of their time in their attitudes, values, social relationships, and expectations of what life had to offer. That is, they were devotedly churchgoing, unskilled, and untraveled, eking out a meager existence at the end of the Great Depression, the father as a factory employee and the mother as a housewife, living in rented, small, inner-city apartments in Indianapolis. That experience of poverty and deprivation, that limited and limiting life, marked them as it marked Bob. Rural Indiana was not going to be his place if he could help it, he decided early in life. He began dreaming of something different, 
more adventurous, more meaningful than fifty-mile family reunion car trips between Indianapolis and Spencer. I know the feeling well, coming from a village background myself.

An awareness of places beyond the dusty, featureless horizons of the rural Midwest came to Bob slowly, through big books and bigger encyclopedia sets that traveling salesmen sold to families keen to give their children an education they themselves did not have, and through the bedtime stories that his mother read to him. One book-the first he really remembered-that made a deep impression on him, that fired his imagination and interest in strange and faraway places (after all those years, he still had a copy of it), was Richard Halliburton's Complete Book of Marvels (I94I). It is an accessibly written and profusely illustrated collection of stories that curious children everywhere still find enchanting: stories about great rivers, bridges, pyramids, and tall buildings, about mythical places and monumental historical events, about Athena's Temple, and Kheope's and Khepron's tombs, about Alexandria and the Tiger of the Alps. Even now, more than a half century later, they make faraway places come alive, their magic fresh. For instance, Baghdad (before the bombs!): "The domes are shining so brightly they seem to be on fire. Groves of palm trees close around them, trees that wave in the hot desert wind. A broad river, lined with garden, flows nearby. Overhead is the burning sunset sky" (Halliburton I94I, I 59).

Bob went to Arsenal Technical School with no idea of what he really wanted to do, trying his hand at carpentry, drafting, and print workshop. Literature and history, as taught by Midwestern teachers with limited intellectual and cultural backgrounds, with emphasis on dates and dry facts, held no appeal for him. That deadening experience of rote learning is familiar to many of us. More interested in sports than study—sports, not religion, is the opium of the masses, including well-heeled university professors!-Bob left high school with an undistinguished academic record. He also left behind him a narrow fundamentalist faith that regarded all pleasure-giving things as evil-drinking, smoking, sex, cinema, even soft drinks-and a culture that regarded anything different-Jews, Catholics, African Americans, and other minority groups—as undesirable and threatening.

After high school, university. Ambition was one thing, though, and financing university education quite another. That problem, too, is familiar to many of us. Fortunately for Bob, the Korean War provided a way out. By 1954, the shooting war was over, but young boys, including 
many of Bob's friends and contemporaries, were still being drafted into the army. Draftees were entitled to three years of university education on the GI Bill, volunteers four years. Bob volunteered. He joined the army. Unfortunately, accounting and finance, his allotted tasks there, did not suit Bob's temperament, and his lack of enthusiasm was noticed. Prospects for promotion and a fatter paycheck looked decidedly bleak. Bob began looking for alternatives. When an overseas posting opportunity presented itself, a friend - a fellow Hoosier in the personnel section — managed to get him listed for Hawai'i. The other alternative-no alternative at all—was a winter posting in Korea.

In December 1955, Bob took a troop ship to Honolulu. He recalled: "I had no idea that the voyage upon which I was embarking would have enormous consequences for the rest of my life." His first encounter with the Pacific taught him that Magellan was flat wrong-even though he did not know then who Magellan was, he told me with a chuckle. The Pacific Ocean was anything but pacific. Hawai'i was different, though. It hooked him the moment he saw it for the first time from the deck of his ship at dawn, just before Christmas I955. "I knew I was seeing something special," he said, "something very special. I was struck by the place. Nothing in my imagination had prepared me for this experience." The contrast with what he had left behind could not have been greater. Nor more welcome.

By the time his tour of duty was over two years later, Bob had decided to stay in Honolulu, lured by the seductive beauty of the place, its relaxed multicultural lifestyle, and the youthful pleasures of the beer-soaked beach culture of Waikìkì. He was scheduled to leave in August, enough time to get his papers processed. Unfortunately for him, the departure date had been advanced to July without his knowledge, the discharge papers still not finalized. Rules were rules, the orders had been issued, and he had to leave. Bob returned reluctantly to the mainland in 1957 to begin college. In hindsight, he did not regret his enforced departure. Had he remained behind, he feared, he might have easily joined the sand-and-surf crowd. It was one of those fateful, unexpected moments, unwelcome at the time, that changes one's life, he recalled-in this case for the better. That sense of unpredictability, the role of chance, is also familiar to many of us.

He enrolled at the Missouri Valley College in the fall of 1957. There he met Lowell D Holmes, freshly graduated from Northwestern University and the sole instructor for all courses in sociology and anthropology. Holmes had done a restudy of Margaret Mead's work in Sāmoa, 
and his courses were heavily infused with cultural anthropology. That was appealing because, as Bob told me, "I do not recall having heard of anthropology before, and certainly it was not a household word in the American Midwest of the I950s." Those courses reignited his interest in exotic places, now rosily colored by the exhilarating two years in Hawaici. Bob recounted: "I was immediately drawn to the discipline, particularly cultural anthropology. It helped make sense of what I had experienced in Hawai'i, and it offered a vehicle for an involvement in the Pacific."

The new discipline promised intellectual liberation. "Anthropology was also brave enough to tackle questions about the diversity of human cultures and races, and intellectually it was much more satisfying than the fundamentalist Christianity that I had known as a youth," he said. The holistic approach of the discipline toward understanding the nature of human evolution and cultural diversity-dealing with real people, real places, real issues-appealed to Bob. He knew early on at college that he wanted to become an anthropologist, and he was determined to pursue his dream. And so, after a couple of years at Missouri Valley, Bob transferred to Indiana University, where he graduated as an anthropology major and Phi Beta Kappa.

Two universities offered graduate programs of the kind Bob had in mind. One was Stanford, under Felix Keesing, the internationally distinguished, New Zealand-born anthropologist who had worked in New Zealand and Sāmoa. ${ }^{1}$ The other was Oregon, under Homer G Barnett, a brilliant, intensely private scholar with a theoretical bent who had worked in Micronesia (Palau). ${ }^{2}$ Both were interested in applied work, and both were interested in Bob. The Woodrow Wilson scholarship to Stanford, which Bob won in a national competition, was for one year only, although Keesing promised further funding. Oregon offered a National Defense Education Act (NDEA) fellowship for the full duration of the graduate program. The NDEA fellowships were established by the US Congress in I96I in the aftermath of Sputnik to support graduate work in the sciences, including anthropology. Financial security settled the choice of graduate school, the prestige of Stanford notwithstanding. As it happened, Keesing died soon afterward.

At Oregon, the anthropology department required its graduate students to have some experience of ethnographic fieldwork before choosing their dissertation sites. Bob chose the Crow Indians on the Montana reservation. Robert Lowie, a leading figure in early American anthropology, had done extensive work among the Crow, focusing on traditional Crow cul- 
ture before its disruption by European contact. ${ }^{3}$ In Lowie's work, Bob came across the Crow's practice of peyotism, a syncretic religious movement that had spread among several Native American groups. It involved the consumption of the peyote plant, a mild hallucinogenic cactus prohibited by federal law. Also known as the Native American Church, peyotism was one response to the trauma of contact with Western society. Bob conducted field research with the Crow in the summer of 1962, and in the following academic year he prepared a manuscript on Crow peyotism. His manuscript and field notes are deposited at the Crow Community College now located on the reservation. Bob saw his work with the Crow as a fallback in case he was unable to work in the Pacific. As he said, it would actually have been "far easier to return to Montana for further research, which would have shortened my doctoral dissertation by at least a year or more. I am grateful that I never had to make that choice."

Homer Barnett supervised Bob at Oregon. Barnett was a long-established fieldworker, one of a group of distinguished American anthropologists with international reputations who had worked in Micronesia in the postwar period under the aegis of large research projects sponsored by the United States Commercial Company (USCC) or the Coordinated Investigation of Micronesian Anthropology (CIMA). ${ }^{4}$ The names of those who were there are legion: Leonard Mason, Douglas Oliver, Alexander Spoehr, George Peter Murdock, Ward Goodenough, William Lessa, David Schneider, Saul Riesenberg, Melford Spiro. Barnett was a part of the cima project under which he gathered material on the Palauans and their experience of colonialism. Between I95I and I953, he served as staff anthropologist for the United States Trust Territory of the Pacific Islands (USTTPI) and was also a member of the research council of the newly formed South Pacific Commission.

From Barnett's Pacific experience evolved a major National Science Foundation-funded project called the Displaced Communities in the Pacific Project (DCPP). Its aim was to study variables affecting cultural change and stability in displaced communities in the Pacific Islands-communities like the Bikinians, Banabans, Southern Gilbertese, Ambrymese on Epi, and Kapingamarangi homesteaders on Pohnpei. Barnett hoped his graduate students would study the process of migration or relocation and the ways in which the resettled communities had evolved new adaptive social and cultural patterns. Their research would provide him material to understand the broader theoretical questions of cultural change that had been his deep intellectual interest. ${ }^{5}$ 
As part of the DCPP, Barnett offered Bob the opportunity to work with the former inhabitants of Bikini Atoll in the northern Marshall Islands, which was then part of the USTTPI. In 1946, the Bikinians were moved from their ancestral homeland to make way for the nuclear tests the United States conducted there soon after the war. With little acquaintance with Pacific Island cultures and societies and even less interest in them, the Americans assumed that all Islanders were peas in the same pod, who could be moved about from place to place with minimum disruption to their lives. So the Bikinians were removed to Rongerik, an uninhabited atoll close to Bikini in the northern Marshalls, because to US officials, "Bikini and Rongerik look alike as two Idaho potatoes," said Bob to me (pers comm).

They could not have been more wrong, for Rongerik was small, poor, and unable to support the small community of relocated Bikinians. Realizing the disaster, the US military resettled them on Kili Island in 1948. But Kili was not Bikini. Bikini is a necklace of twenty-six islands along a coral reef encircling an enormous lagoon rich in marine resources. Kili in the southern Marshalls lies in a different ecological zone. It is small, oneseventh the size of Bikini. It has no lagoon or sheltered fishing area and is frequently at the mercy of rough, open seas. Culturally, too, the new migrants bore the brunt of harsh treatment. The southerners considered them backward, of low pedigree and inferior speech. The hosts' attitude of superiority reinforced the low esteem and unflattering image the Bikinians held of themselves. In short, life for the new migrants was tough. As Bob found out, the "Bikinians compare it [Kili] to a jail, and they have been an unhappy, frustrated, and not infrequently angry people since their relocation. Today they are discontented, dependent wards of the United States."

From Bob's Bikini work came his 1967 doctoral dissertation, "Changing Patterns of Land Tenure and Social Organization among the Ex-Bikini Marshallese," and a I968 report for the DCPP titled Kili Island: A Study of the Relocation of the Ex-Bikini Marshallese. In I974, Bob published his major Bikini work (based on earlier studies), The Bikinians: A Study in Forced Migration. The book was well received as an important contribution to the growing field of the anthropology of colonialism as well as to what anthropologists call "extended case studies." While Bob's empathy with the people he worked with was clear, what was especially striking was his deep disappointment with US policy in Micronesia. "In the Pacific as well as North America," he concluded in his book, "Americans have assumed a cultural and racial superiority which they believe justifies 
their disruption of the lives of dark-skinned peoples and the seizure of the latter's real estate for American ends. The manner in which restitution is sometimes attempted offers another similarity: after-the-fact provision of financial compensation and other poorly conceived welfare measures appear to ease the conscience of Americans and allow them to avoid examining the consequences of their acts" (Kiste [1974], I98). Bob told me he was proud of his Bikini book, pleased that it "has been accepted as an accurate account of the Bikinians' troubled history," proving "useful to the Bikinians in their many legal battles with the United States." He would have been deeply gratified to know that at a memorial held in spring 20I8, in the Pacific Collections of the University of Hawai' $i-$ Mānoa Hamilton Library, that the Consulate of the Republic of the Marshall Islands honored his significant contribution to their communities and nation with word and song.

After his research with the Bikinians, Bob conducted fieldwork with the people of Enewetak, another atoll in the northern Marshalls, and his most direct public intervention arising from his Micronesian work was on their behalf. The Enewetak people were the second community to be relocated by the Americans. When their atoll was selected for further nuclear testing by the United States, the Enewetak people were moved to the uninhabited Ujelang Atoll in 1947. Like the Bikinians, they never lost their desire to return to their ancestral homeland, and in the early I970s they protested when further military activity was contemplated that would inflict more environmental damage to Enewetak. They took advantage of the recently created Micronesian Legal Service Corporation (MLSC) and took their grievance to court.

Bob was consulted by the MLSC. He was part of a fact-finding mission to Enewetak and Ujelang and served as a witness at legal hearings in Honolulu. ${ }^{6}$ His own position was clear: "I was obligated to the Enewetakese. They had befriended me, tolerated my inquiries into their lives, and had thus made my own fieldwork possible. When an issue that had significant consequences for their future was being contested, I felt I had no choice but to help challenge those who represented a threat to their well-being." He had no regrets about his participation, although he acknowledged that he was by nature uncomfortable with public confrontations in emotionally charged situations "when one is questioning the basic intentions and honesty of others." His advice to his colleagues? Writing in the I970s, he said: "As events progress in Micronesia and as Americans continue to manipulate the islanders for their own ends, I suggest that a greater num- 
ber of us in the profession will not easily escape the obligations we have to those who have made our work in Micronesia possible" (Kiste 1976, 77). Like most of us, Bob was not an "uninvolved ethnographer."

Fieldwork is never just about collecting research data. It introduces the researcher into a whole new web of relationships full of unanticipated obligations and responsibilities, often producing bonds of friendship that endure across time and place. It was so for Bob. He discovered that the Bikinians were adept ethnographers themselves, just as curious about Bob's country as he was about theirs. When Bob told them about John F Kennedy's assassination by Lee Harvey Oswald, the Bikinians assumed straightaway that Oswald must have become the new president. In preEuropean times, people who assassinated chiefs succeeded them. And Bob could not quite explain the "size of his island" to inquisitive Bikinians, nor respond adequately to the question he was asked on a moonlit Kili beach about what Americans were doing on the moon: "Why is it that Americans are so smart they can put men on the moon, but they can't solve our problems here?" One sadness that Bob had about his Bikini experience was that he did not get to know Chief Juda better and record his life story for posterity. The chief, Bob said, was a wise, gentle leader of a people in distress.

Still, for all his affection for the people and the place, Bob did not continue sustained research on Bikini. I wondered why. The unfolding Micronesian saga, embroiled in large geopolitical questions, was getting messier, he said. Narrow legalistic matters had taken on a life and momentum of their own, something that many scholars, no matter how involved or passionate about their subject, find distasteful and sometimes frankly intimidating. Moreover, the Bikinians of the early r960s were not the same people in 1969. Their image of themselves as a backward, unsophisticated people had changed dramatically within a decade. They had become skilled at representing their grievances and demands to the international community, and by reciting a sorry tale of neglect and damage and injustice, they sought to have the Americans shoulder the responsibility for their welfare. As Bob put it, "By determining the locus of responsibility for their situation, the Bikinians' total history has become a political ideology that defines both themselves as victims and their current relations with their former chief and colonial power in a single interpretive framework" (Kiste I977, II8). Bob found that dependent, handout mentality disconcerting. And there were intellectual reasons for moving on as well. Bob was not an inveterate ethnographer interested in doing one case study after another. The Pacific had other mysteries he wanted to explore. 
One night in 1964, on his way back from fieldwork, Bob was invited to Leonard Mason's home for dinner. Mason, another long-term researcher in Micronesia, had been a source of much-valued advice and help to Bob, who had begun his Bikini work under his tutelage. The friendship between the two lasted nearly half a century. Also present at dinner that night was E Adamson Hoebel, a major figure in American anthropology, and then chair of the anthropology department at the University of Minnesota. ${ }^{7}$ In awe of the great man, Bob said little that evening. A year later, when Bob was writing his dissertation in Oregon, Hoebel called to say he had been impressed with him at dinner that evening in Honolulu and wondered whether Bob would be interested in joining the faculty at Minnesota. Bob was interested (and was hired, along with his lifelong friend, Eugene Ogan). Hoebel had been impressed because Bob was a good listener! Respectful silence and deference to authority in the presence of potential benefactors can be a virtue. Is this a classic Micronesian (and perhaps a wider Pacific Island) lesson?

Minnesota was intellectually fulfilling, and Bob rose rapidly through the ranks to secure tenure and promotion in a well-regarded anthropology department. ${ }^{8}$ But Hawai'i continued to beckon, the attraction strengthened by a $1972-73$ sabbatical there and a semester as a visiting professor at the University of Hawai'i in the fall of 1976 . The presence of old friends and mentors along with the memory of long, hard Minnesota winters suggested a move. In 1978, Bob finally left Minnesota for Hawai'i for good. He was hired to build what eventually became the Center for Pacific Islands Studies. It is one of the world's premier centers for Pacific Islands research and teaching, and its success is without doubt due to Bob's untiring effort and enviable abilities as a fund-raiser and skills as an administrator. His contribution is best appreciated against the backdrop of what he inherited when he appeared on the scene.

Pacific studies at the University of Hawai'i had begun haphazardly, gaining momentum after World War II, ${ }^{9}$ when much of Micronesia came under the administrative umbrella of the USTTPI. Parts of the region were closed off to outside scrutiny, and the US military had established a firm grip on strategic locations. Atomic devices were tested, missile test sites established, Islanders dislocated and resettled. The advent of the Cold War intensified the American hold on the area. Anthropologists were hired to gather social, economic, and cultural data to assist the postwar reconstruction effort. Among them were Leonard Mason, whose entire professional career was spent at the University of Hawai' $i$, and Douglas Oliver, who later came to Honolulu from Harvard. Both were instrumental in 
the development of Pacific studies at the University of Hawai'i along with political scientist Norman Meller, a significant scholar of Micronesian constitutionalism. Mason, the inaugural director, did what he could with what few resources he had, organizing and coordinating research projects, convening seminars, seeking outside funds, building up the Pacific Collection at the Uнм library, and generally creating a consciousness of the Pacific in the community and among federal bureaucrats.

By the time Bob was appointed director in I978, there was serious debate on the campus about the future of the Pacific Islands Studies Program (PIP), as it had become by then. Mason and Meller wanted to maintain and strengthen it, while Oliver was not convinced of its intellectual merit and recommended its termination. Oliver was a firm nonbeliever in the value of cross-disciplinary programs. Mason and Meller's faction won the debate, and Bob was lobbied to apply (by Oliver, of all people, who managed to have himself appointed as chair of the search committee so he could shape the outcome he wanted!) for the temporary, one-year renewable position as associate professor. Although Bob was a full professor at Minnesota, he opted for the temporary position. He was forty-two years old. The Pacific tug proved irresistible, and Bob did not want to be haunted by the question, "What if you had not done it?" He recalled his decision this way: "I could not have asked for a better opportunity. The chance to develop a Pacific program was an exciting prospect and a challenge."

Changing old habits of thought on the campus did not prove easy, though. The university budget was tight, and the Pacific was on the administration's back burner. But eventually Bob succeeded where others had faltered. The program "had nowhere to go but up," Bob said with characteristic modesty, but there were, in fact, other reasons. Unlike his predecessors, Bob was able to become full-time director of the center, thanks to the generosity of the university's Social Science Research Institute, which paid half his salary and released him from teaching and administrative duties to put the program "back on its feet." The Pacific faculty, especially the old guard, to their great credit, forgot their differences and rallied behind Bob. On the campus, there was an increased awareness of the importance of the Asia-Pacific region, reflected in the creation in 1980 of the Center for Asian and Pacific Studies (CAPS). The changing mood in Washington also helped, with the US Department of State establishing its own Office of Pacific Island Affairs in 1978, which was staffed at various times by the Pacific Islands Studies Program's own graduates. Bob's efforts secured federal funding, and in the early I980s the US Department of Education 
recognized the Center for Pacific Islands Studies as a National Resource Center-the only one in the nation that focused on the Pacific.

Funds flowed, which enabled Bob to enlarge the center's activities to facilitate workshops and conferences, mount outreach programs, enable faculty exchange, and bring distinguished Pacific Island public figures to the Mānoa campus. Bob gave the center a region-wide visibility that it had lacked before. He extended his network beyond Hawai'i. For several years, he regularly attended meetings of the (then) South Pacific Commission, where he personally came to know many Island leaders and policymakers. He also briefed American diplomats and others heading for the Pacific. The time for takeoff had arrived, and Bob, with his "organizational skills, diplomacy, and sound judgment," to use Mac Marshall's words, was the right man at the right time to be at the helm (Marshall 2004, 39).

Bob continued to be a productive, though not a solitary, scholar. He edited books and wrote a biography of the Fijian public figure Macu Salato, besides numerous conference presentations and consultancy reports. ${ }^{10} \mathrm{His}$ graduate students remember him warmly as a dedicated teacher, culturally sensitive and committed to bringing out the best in them. Bob also devoted a considerable part of his time to institution building. Pacific Collection Librarian Karen Peacock remembered Bob's total commitment to "maintaining an international reputation for excellence in the Pacific Collection" and "his understanding of the need for a library to support research unparalleled in my experience" (pers comm). Pacific faculty members at Mānoa remember how Bob was somehow able to find extra funds to facilitate their summer research or finance a conference trip. And Bill Hamilton, former director of the University of Hawai'i Press, remembered him as a "true advocate of the Press," having served on its editorial board from I 986 to 2006. As reader, reviewer, and adviser, Bob made a difference. In a personal note to me, Bill recalled "Bob's extensive Pacific Islands network of scholars, political leaders, and government officials, his recommendation that they consider us as their publisher, has led to numerous publications by the Press."

Tisha Hickson, former outreach coordinator at the Center for Pacific Island Studies (CPIS), offered a few suggestions as to why Bob was such a successful director. The center "works the way it does, and feels the way it does, primarily because of Bob's vision," she said. Bob always valued the common purpose above all else. "The emphasis was on 'we' rather than 'I,' and he was unstinting in his praise for the good work that others have done. There was always an excitement about what we could do, and Bob was always the first to credit others with good ideas." His collegiality and 
diplomacy bonded the team. "There was a remarkable absence of social hierarchy at the center," she said. Bob would never ask anyone on the staff to do anything he himself was not willing to do. He would push the office refrigerator out on the landing to defrost, make the morning coffee, and take the parking space farthest from the building. This "appreciation of others reflected a true generosity of spirit," Tisha said. Those who knew Bob would agree wholeheartedly.

Building the Center for Pacific Islands Studies into a world-class institution was a significant personal and professional achievement, but Bob was best known - and will probably be best remembered in the future-as the publisher of scholarly monographs on the Pacific. He was the founding general editor of the first sixteen volumes of the Pacific Islands Monograph Series (PIMS) copublished with the University of Hawai'i Press (now under the editorship of Tarcisius Kabutaulaka). That series constitutes a benchmark in Pacific scholarship; it has no rival and is not likely to have one anytime soon. What is remarkable about the books is not only the pioneering quality of their scholarship in a range of disciplines (with history dominating) but also their elegant look and craftsmanship. Bob was well served by his manuscript editors Linley Chapman, who was associated with the project since its inception, and, after Chapman's retirement in 200I, Jan Rensel. The South Sea Books, another of his publishing ventures intended to publish popular works on the Islands region, had a mixed reception and has now been combined with PIMs.

Bob was also instrumental in the publication of The Contemporary Pacific: A Journal of Island Affairs (TCP), serving as the chair of its editorial board from the first issue (I989) through volume I4, issue I (2003). His mode of operation was revealing of the man. I speak from personal experience as the journal's founding editor. Bob was TCP's ambassador, its representative in the corridors of power, a staunch defender of its integrity and goals. He was, by and large, a good judge of character. Once he had assembled his team and reposed his trust in them, he allowed them the maximum freedom to do things as they saw fit. He never secondguessed their decisions, never interfered, even-or especially-when some submissions from close colleagues and friends had to be rejected. His commitment to excellence was absolute, unwavering, and inspiring. It is no wonder that the journal is internationally esteemed, like the monograph series, for the quality of the scholarship it publishes and, as an added bonus, for its handsome production.

Bob began his intellectual journey as a professional anthropologist. 
Had he remained at Minnesota, he might well have plowed a more conventional career path. He was quietly saddened by the new directions the academy had taken, and more particularly in his own discipline. As someone from his background, committed to the idea of using scholarship to solve human problems, interested in contemporary developments, in real people and real places, he despaired at the intellectual fragmentation of scholarship. Anthropologists, he said to me, know more and more about less and less. They often ask questions that have little relevance and even less meaning. The lexicon and grammar of postmodern discourse was alien to Bob: in truth, he cared little for or about it. He was a man of his time and place. He was passionate about the Pacific, though there, too, was private regret about the way some Islands were then conducting their affairs, squandering time and opportunity that Bob saw as so nearly within their reach to realize the potential that was undoubtedly there. $\mathrm{He}$ felt it was time for him to move on, to continue in retirement his long, unpredictable, improbable but ultimately exhilarating journey from Spencer, Indiana, to the Islands of the Pacific.

After Bob retired from CPIS in 2002, he joined the East-West Center's (EWC) Pacific Islands Development Program (PIDP) as an Adjunct Senior Research Fellow, cementing a long and remarkable collaboration between CPIS and PIDP (Kiste 2008). Bob remained impactful in his post-retirement role at the EWC helping found and coedit the Pacific Islands Policy Series with PIDP's Director Jerry Finin. Bob kept in notable good touch with many of his former students and colleagues. And he continued to travel, including to Machu Picchu, the Amazon, Patagonia, and Terra del Fuego, and served for many years as a lecturer about the Pacific Islands on Smithsonian's annual Pacific Islands Cruise. Bob passed away on 28 November 2017 .

I want to conclude by stealing a story from Mike Rynkiewich's contribution to Pacific Places because it brings a number of strands together. Mike was Bob's first doctoral student, Hoebel was the one who hired Bob at Minnesota, and there is reference to place, underlining for me the theme of interconnectedness and the essential emptiness of essentialism that runs through Places. Mike was defending his doctoral proposal when Bob asked him, "What right do you have to go out and disturb someone else's life just so you can get your $\mathrm{PhD}$ ?" Taken by surprise at this question from the chair of his dissertation committee, of all people, Mike responded somewhat uncertainly, "Anywhere I am in the world, I have to live with other people. People do things for me and I do things for people. 
It won't be any different in the Marshalls." Hoebel laughed, recalling a story that not only let Mike out of a tight situation but also has a larger message. "You remind me of the man I once saw in a movie," Hoebel told Mike. "He was visiting his friend's wife when his friend came home. The husband was suspicious so he looked around, eventually opening the closet door. 'What are you doing here?' he shouted. With a shrug of the shoulders, the man replied, 'Everybody's gotta be somewhere'" (Rynkiewich 2004, 3I2).

I am grateful to David Hanlon, Kerry Howe, Doug Munro, Karen Peacock, Eugene Ogan, Mike Rynkiewich, and especially Mac Marshall for their comments and advice on a draft of this essay. To Bob Kiste I am grateful for many things over many years, but on this occasion especially for talking to me at length about his life and work. Jan Rensel, Zakea Boeger, and Alexander Mawyer offered suggestions and support on the updating and revision of this piece.

\section{Notes}

I Among Felix Keesing's most influential works was Cultural Anthropology: The Science of Custom (1958). His books on the Pacific include Modern Samoa: Its Government and Changing Life (1934) and Elite Communication in Samoa: A Study of Leadership (1956).

2 Homer G Barnett's major Palauan work is Palauan Society: A Study of Contemporary Native Life in the Palau Islands (1949). His major theoretical work is Innovation: The Basis of Cultural Change (1953).

3 Robert Lowie's books include Primitive Society (I92 I) and An Introduction to Cultural Anthropology (1940).

4 This discussion is based on Marshall 1999.

5 Barnett was unable to realize his dream, but some of the fruits of this project may be found in Lieber 1977. That book is dedicated to Barnett, "who began this work and showed us what culture change is all about."

6 Bob's involvement in that case is described in Kiste 1976.

7 Bob recounted this in the preface to American Anthropology in Micronesia (Kiste and Marshall I999).

8 At Minnesota, Bob chaired two doctoral dissertations on Micronesia: Schaefer 1976 and Rynkiewich I972. He also chaired Wohlt I978, beside several others on other topics and places.

9 For this account I have drawn on Quigg I987, as well as conversations with colleagues at UHM. 
Io Bob's edited books include Tides of History: The Pacific Islands in the Twentieth Century ( I994), with K R Howe and Brij V Lal, and American Anthropology in Micronesia: An Assessment, with Mac Marshall (1999). His biography is He Served: A Biography of Macu Salato (1998).

\section{References}

Barnett, Homer G

I949 Palauan Society: A Study of Contemporary Native Life in the Palau Islands. CimA Report 20. Eugene: University of Oregon Publications.

I953 Innovation: The Basis of Cultural Change. New York: McGrawHill.

Halliburton, Richard

I94I Richard Halliburton's Complete Book of Marvels. Indiana: Bobbs Merrill.

Howe, K R, Robert C Kiste, and Brij V Lal, editors

I994 Tides of History: The Pacific Islands in the Twentieth Century. Honolulu: University of Hawai'i Press.

Keesing, Felix M

I934 Modern Samoa: Its Government and Changing Life. London: Allen \& Unwin.

I956 Elite Communication in Samoa: A Study of Leadership. Palo Alto, CA: Stanford University Press.

I958 Cultural Anthropology: The Science of Custom. New York: Holt, Rinehart, and Winston.

Kiste, Bob

2008 Interview by Terese Leber, April 30, 2008, interview narrative, EastWest Center Oral History Project Collection. Honolulu, Hawai'i: East-West Center.

Kiste, Robert C

[1974] The Bikinians: A Study in Forced Migration. Kiste and Ogan Social Change Series in Anthropology. Menlo Park, CA: Cummings Publishing Company.

I976 The People of Enewetak Atoll Versus the U.S. Department of Defense. In Ethics and Anthropology: Dilemmas in Fieldwork, edited by Michael A Rynkiewich and James P Spradley, 6I-80. New York: John Wiley \& Sons.

I977 The Relocation of the Bikini Marshallese. In Exiles and Migrants in Oceania, edited by Michael D Lieber, 8 I-I 20. Honolulu: University Press of Hawai'i.

I998 He Served: A Biography of Macu Salato. Suva: Institute of Pacific Studies, University of the South Pacific. 
Kiste, Robert C, and Mac Marshall, editors

I999 American Anthropology in Micronesia: An Assessment. Honolulu: University of Hawai'i Press.

Lal, Brij V, editor

2004 Pacific Places, Pacific Histories: Essays in Honor of Robert C. Kiste. Honolulu: University of Hawai'i Press.

Leuchtenburg, William E, editor 2000 American Places: Encounters with History. A Celebration of Sheldon Meyer. New York: Oxford University Press.

Lieber, Michael D, editor

I977 Exiles and Migrants in Oceania. Honolulu: University Press of Hawai'i.

Lowie, Robert

I92 I Primitive Society. London: Routledge and Kegan Paul.

I940 Introduction to Cultural Anthropology. New York: Farrar and Rinehart.

Marshall, Mac

I999 Ripples from a Micronesian Sea. In American Anthropology in Micronesia: An Assessment, edited by Robert C Kiste and Mac Marshall, 387-43 I. Honolulu: University of Hawai'i Press.

Quigg, Agnes

1987 History of the Pacific Islands Studies Program at the University of Hawaii: 1950-1986. Honolulu: Pacific Islands Studies Program Working Paper Series.

Rynkiewich, Michael A

I972 Adoption and Land Tenure among Arno Marshallese. PhD dissertation, University of Minnesota.

2004 The Place That Is a Part of It. In Pacific Places, Pacific Histories: Essays in Honor of Robert C. Kiste, edited by Brij V Lal, 309-326. Honolulu: University of Hawai'i Press.

Schaefer, Paul D

I976 Confess Therefore Your Sins: Status and Sins on Kusae. PhD dissertation, University of Minnesota.

Wohlt, Paul B

I978 Ecology, Agriculture and Social Organization: The Dynamics of Group Composition in the Highlands of Papua New Guinea. PhD dissertation, University of Minnesota. 